\title{
PRIVATE RESCUE ECHO BEACON WITH FSK RADIOMODULE
}

\section{Introduction}

Rescue personnel work in high-risk environments. As a result of injuries, the problem of evacuating the lifeguard from the facility may arise. GPS navigation is not available in restricted areas, for example, in rooms, basements. Rational use of radio responders for direction finding of the object. A radio direct finding complex is not always convenient and can be quickly deployed, for example, in a basement in case of fire.

\section{Problem Statement}

It is more convenient to use the blind bearing method with existing VHF radio stations. Professional radio stations usually do not have an indicator of signal strength, and have limited controls such as volume, channel selection, and PTT.

It is necessary to create a reliable echo beacon [1], adapted to work with the specified equipment. An audio echo transponder is irrational as a prefix to a radio station, all the more so the victim's radio station with a standard power of 5 watts is convenient for searching from air at distances of tens to hundreds of kilometers [2], but not in a small room [3].

\section{Analysis of recent research and publications}

In paper [4] proposes to combine IMU and radio measurements (i.e., peer-to-peer Wifi received signal strength and peer-to-peer UWB ranging) for the positioning of a group of mobile users in emergency response, where no fixed anchors and no infrastructure are available. We incorporate the IMU and radio measurements into the particle filtering, which has the capability to cooperatively position a group of mobile users and recover from any potential tracking failures. By fusing the long-range Wifi RSS and short-range UWB ranging measurements, we can take the advantages of both sensors and achieve an accurate and robust positioning system.

Work [5] describes a real industrial problem (location and tracking of forklift trucks) that requires precise internal positioning and presents a study on the feasibility of meeting this challenge using UWB technology. To this end, a simulator of this technol- ogy was created based on UWB measurements from a set of real sensors. This simulator was used together with a location algorithm and a physical model of the forklift to obtain estimations of position in different scenarios with different obstacles. Together with the simulated UWB sensor, an additional inertial sensor and optical sensor were modeled in order to test its effect on supporting the location based on UWB. All the software created for this work is published under an open-source license and is publicly available.

In article [6] author describes the way how to implement IEEE802.15.4a physical layer and medium access layer. The system uses time difference of arrivals technique to estimate the position of the mobile device. System can reach an accuracy of $\pm 20 \mathrm{~cm}$ in line of sight measurement and $\pm 50 \mathrm{~cm}$ for nonline of sight measurement. But the localization that is achieved has an accuracy is up to $\pm 1.1 \mathrm{~m}$, we believe this can be improved by having all device to be synchronized effectively.

\section{Research goals and objectives}

Proposed simple beacon (equipment) for indoor search and object location man-assisted and ugly UHF(VHF) handy transceivers based

\section{Results and discussion}

It is proposed to use a carrier transponder at a given frequency based on SI44XX with stepwise adjustable power and synchronously changing audio filling tone in FSK or GFSK mode.

Transceivers SI4432, SI4463, CC1101 [7-9] can be used for this reason. RF power $100-10 \mathrm{~mW}$ is enough. All of them can work in FSK GFSK and ASK modes. Widest frequency range have SI4463 and it cover main bands $136-174 \mathrm{MHz}$ and $400-$ 470(512) MHz.

On SI4463 manufacturers sail vonderful module $\mathrm{HC}-12$, that consists of transceiver, MCU STM8S003 and power supply. HC-11 uses CC1101 transceiver with the same addons $[10 ; 11]$.

Transceivers CC11xx and SI44xx have the almost same block diagrams with little differences, for example on Fig 1. You can see CC1101 block diagram from the TI manufacturer datasheet. 


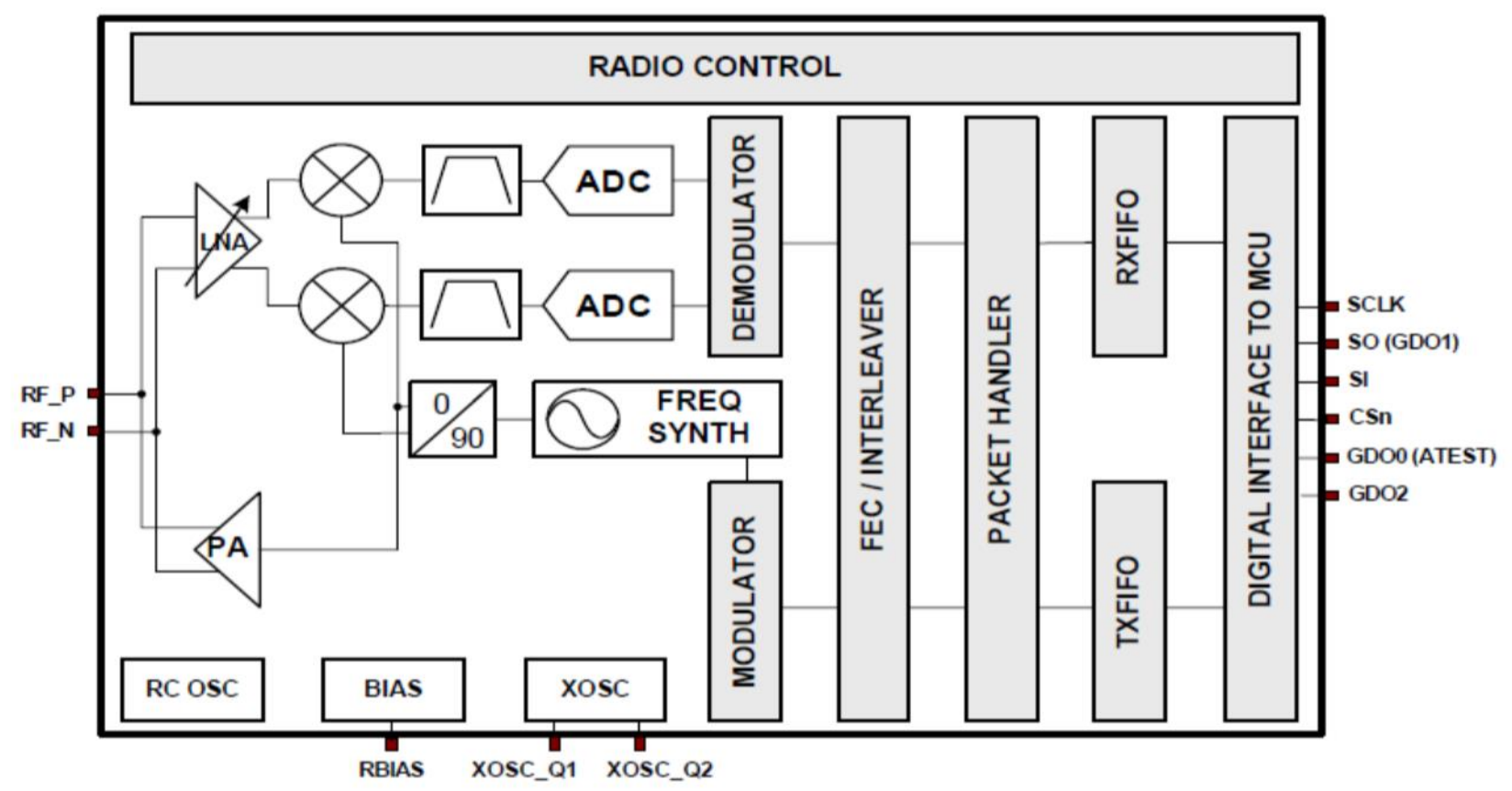

Fig. 1. CC1101 block diagram

MCU is the bridge from SPI to control radio to UART for the communications. On the back side of PCB two pads are programming interface SWD. You can reflash STM8 on Youf firmware and change module usage. You will need ST-Link programmer with the soft like ST-Loader, ST-Link and IDE like STM IAR for STM8 cores. Libraries need is perepherial, timers, GPIO, SPI and sleep.

Module HC-12 block diagram is on the Fig. 2. Antenna connected to the radio thrue LPF on 500 $\mathrm{MHz}$ with $\mathrm{Z}=50 \mathrm{Ohm}$.

You can see that Receive-Transmit SPDT switch is controlled by the STM8 GPIOs. SI4463 controlled via hardware SPI of the MCU. GPIO links to CS pin of radio for usage sleep mode.

External pins of MCU are used for USART and mode SET function. Remember, You also have also two pads of SWD, so we hawe 5 pins for communications with external hardware. They easy can be changed for Your reasons withour any soldering (Fig. 3).

The radio module is controlled via the SPI bus; to generate a tone, one of the GPIOs is configured as a binary data input in FSK mode. To implement the response, the module monitors the change of the RSSI and, if it available, switches to the transmission mode. To control the radio module, a simple 8-bit controller with 8 (6) pins and SPI support is enough.

For understanding the process and firmware, let's build one device on AVR 8 bit MCU. We can use atmega328 with fith bootloader that uses USART for flashing. You can buy any "arduino" board for that. Language in example is Wiring. On this language perepherial ant clock inicialisation looks much friendly. We will need only one library, RF22 for exchange with radio. If You wish, you can use only SPI read/write to registers (Fig. 4).

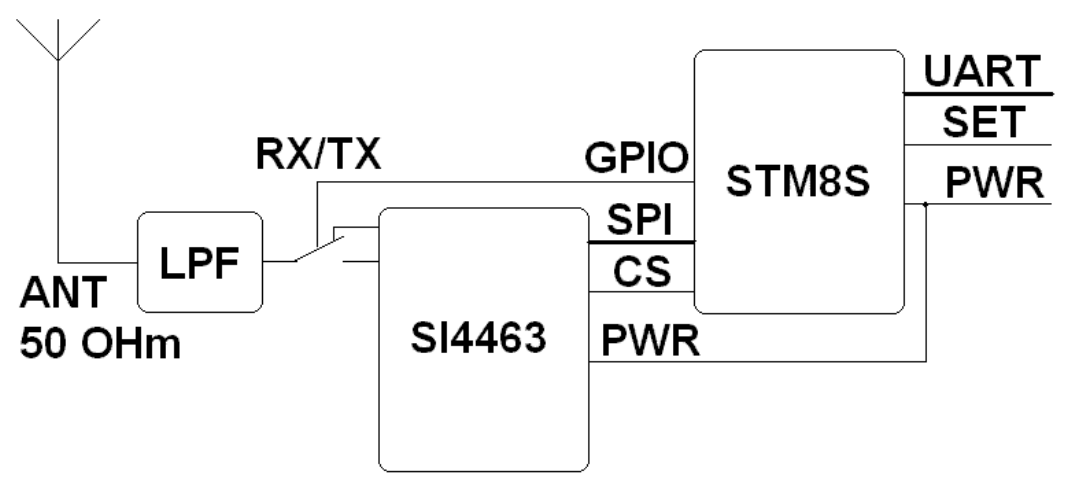

Fig. 2. HC-12 module schematics SI4463 controled by STM8S003 MCU 


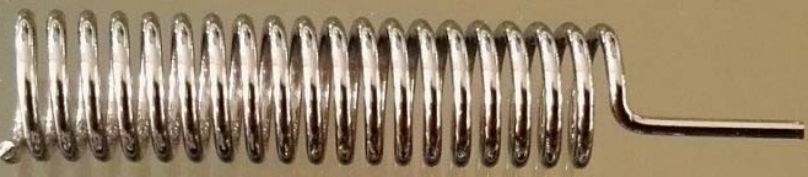

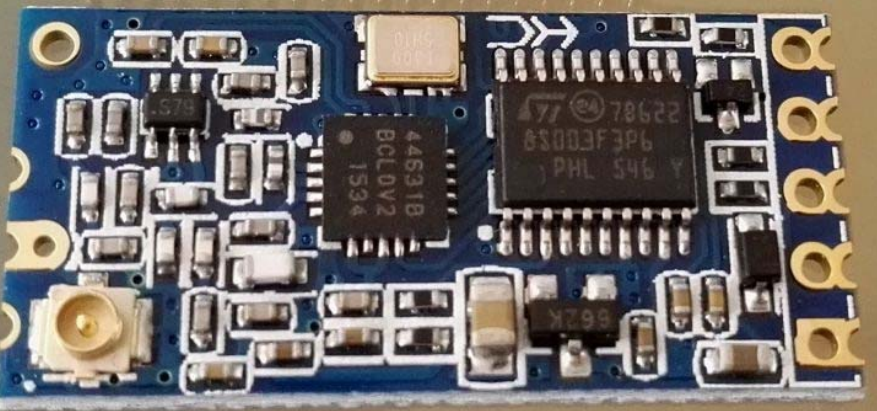

Fig. 3. View and dimensions of HC-12 transceiver module

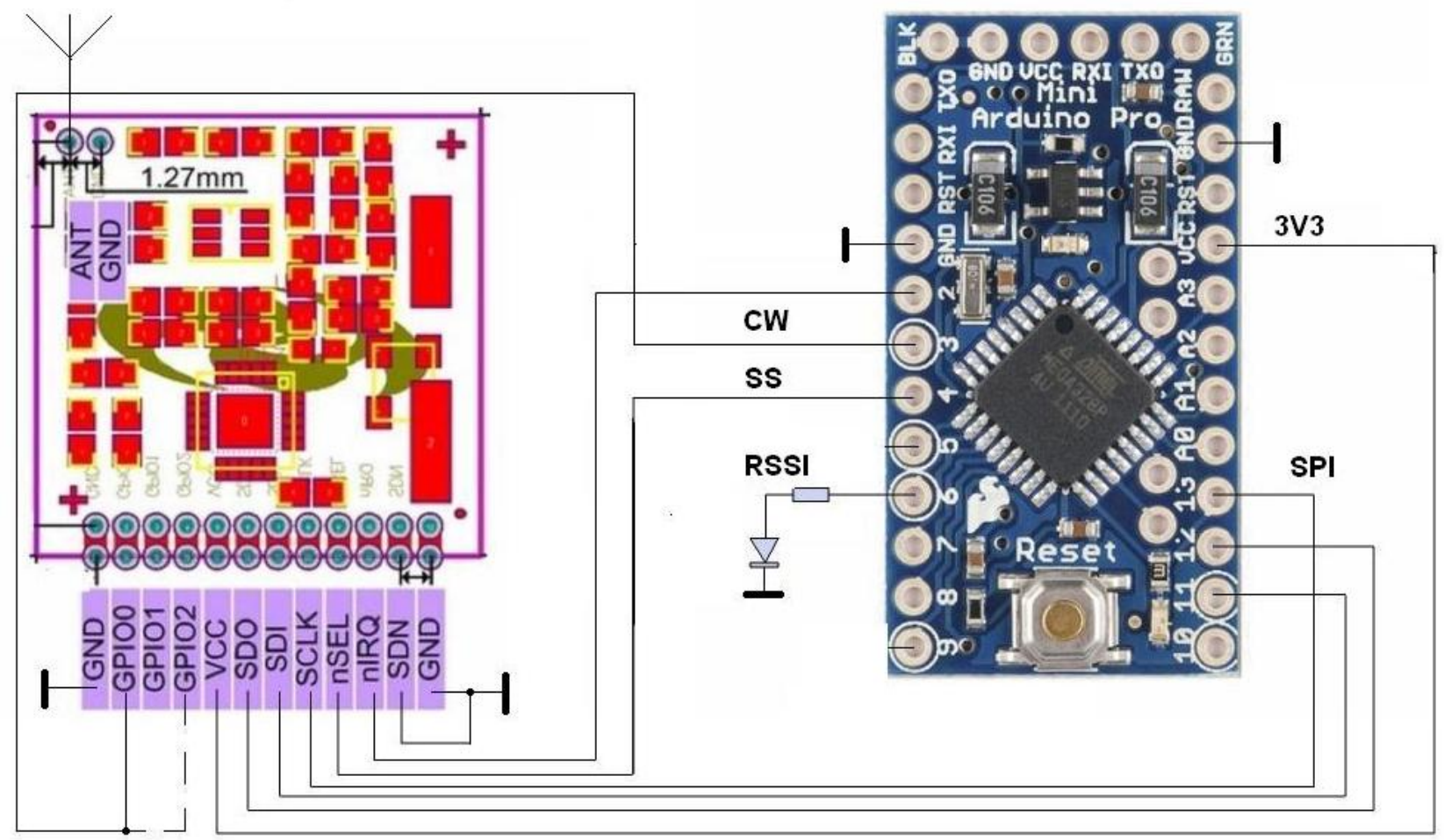

Fig. 4. AVR based beacon on RF22 module - SI4432 radio

\#include $<$ SPI.h $>$

\#include <RF22.h>

Setting frequency of carrier, pins to control transmitter (CW) and for the RSSI led, that will be show signal level by the brightness. SNR - signsl to noise ratio is threshold of transmit $\mathrm{ON}$ trigger in main loop, 20 units is near $10 \mathrm{~dB}$ of RF signal level. \#define Frequency 434.515

\#define RSSI_PIN 6

\#define CW 3 //GPIO0 si4432 SDN=GND

\#define snr 20

Variable to hold previous RSSI

char rssiprev $=0$;
Object - radio module, CE always on the ground. RF22 rf22;

Prepare pins (DDR), and setting work mode for the radio: frequency, power, modulation, deviation, control TX gpios and metods.

void $\operatorname{setup}()\{$

pinMode(CW, OUTPUT); digitalWrite(CW, LOW); pinMode(RSSI_PIN, OUTPUT); analogWrite(RSSI_PIN, 0);

rf22.init(); rf22.setFrequency(Frequency, 0.005); rf22.setTxPower(RF22 TXPOW 20DBM); rf22.setModemConfig(RF22::FSK Rb2Fd5); rf22.setModeRx(); 
rf22.spiWrite(RF22_REG_71_MODULATION_CON TROL2, 0x42);

rf22.spiWrite(RF22_REG_0B_GPIO_CONFIGURAT ION0, 0x12);

Infinity loop check variables of input RSSI and if it is more than threshold, puts TX ON.

void $\operatorname{loop}()\{$

if $((\mathrm{rf22} \cdot \mathrm{rssiRead}()>$ rssiprev + snr $)$ \|

(rf22.rssiRead ()$<$ rssiprev - snr)) \{

rf22.setModeTx();

Transmitter once a second change it output power 100-10-1 mW and transmit variable audio tone in frequency modulation, via CW pin of the MCU, 500$1000-1500 \mathrm{~Hz}$ that can be easy determinate by the operator.

rf22.setTxPower(RF22_TXPOW_20DBM); tone(CW, 500, 1000); delayy(1000); noTone(CW);
rf22.setTxPower(RF22_TXPOW_11DBM); tone(CW, 1000, 1000); delay(1000); noTone(CW); rf22.setTxPower(RF22_TXPOW_1DBM); tone(CW, 1500, 1000); delay(1000);noTone(CW); rf22.setModeRx();

Transmitter OFF after last tone transmit, RSSI renew, and sets a little delay.

analogWrite(RSSI_PIN, rf22.rssiRead()); rssiprev = rf22.rssiRead(); delayy(1000); \}

Calculations of free space path losses on $433 \mathrm{MHz}$ shown on Fig 5. Pay attention, that $20 \mathrm{~dB}$ for "force majore" added. Without any licens You can use devices on LPD and PMR bands. Author have amateur radio licens - callsign UT5UUV, so can use radios outstanding shown bands.
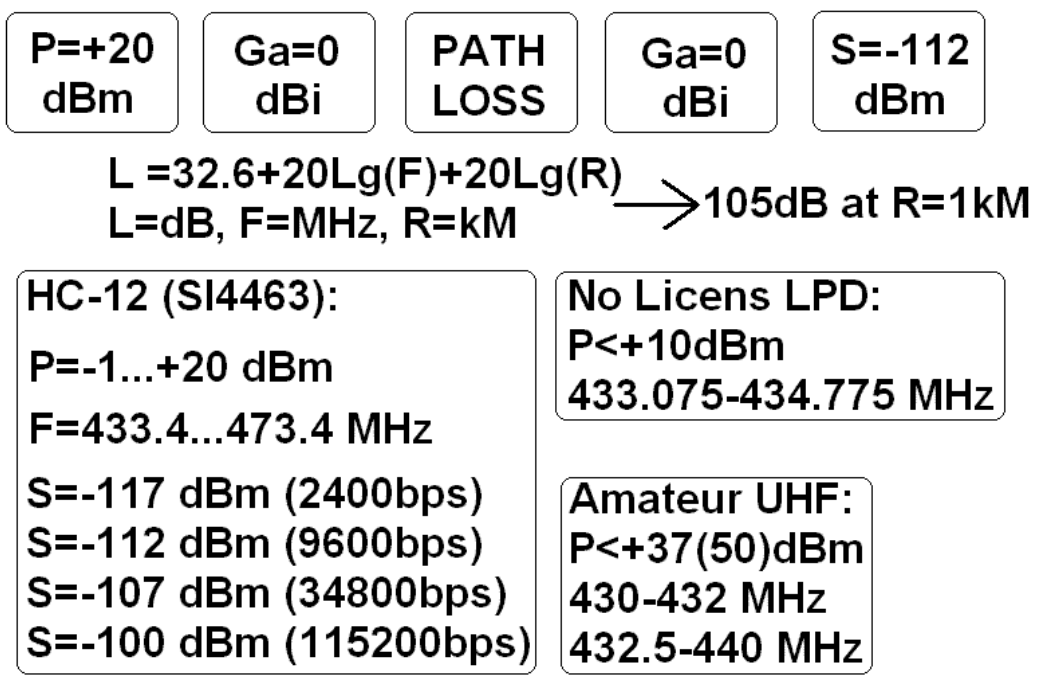

\section{No Licens LPD: $P<+10 \mathrm{dBm}$ 433.075-434.775 MHz}

Amateur UHF:
$\mathrm{P}<+37(50) \mathrm{dBm}$
430-432 $\mathrm{MHz}$
$432.5-440 \mathrm{MHz}$

Fig. 5. Path loss calculation for UHF radiolink on SI4463 transceiver

\section{Conclusion}

A power of $100 \mathrm{~mW}$ is more than enough, even with a very shortened helical or other surrogate antenna. Search range of hundreds of metrs is allowed. The number of RF power levels can be 3-4. It can be incree to 7 with an external attenuator on SPDT keys. The power change step is $6-10 \mathrm{~dB}$.

The tones are rising, clearly audible in the range of 400-2000 Hz.

This system, after the staff training can be useful in the search for the victim in conditions of zero visibility with an accuracy of less than a meter to a few meters in the premises.

\section{REFERENCES}

1. UT5UUV // [Electronic resource] // - Access: http://www.qrz.com/db/UT5UUV

2. Мошенський А. О. Прогнозування умов радіозв'язку на основі комп'ютерної обробки даних підчас змагань 3 радіозв'язку. Наукові записки УНДІЗ. 2012. №1(21). С.227-236 с.
3. Мошенський А. О., Горілий В. Програмноапаратний комплекс для моніторингу торф'яних пожеж на радіоактивно забрудненій території. Наукові прац̧і НУХТ. 2019. Том 25. №2. С. 16-21

4. Ran Liuab, Chau Yuenb, Tri-Nhut Doc, Meng Zhangd, Yong Liang, GuaneU-XuanTanb. Cooperative positioning for emergency responders using self IMU and peer-to-peer radios measurements. Information Fusion. April 2020. Volume 56. P. 93-102

5. Barral V., Suárez-Casal P., Escudero C.J., García-Naya J.A. Multi-Sensor Accurate Forklift Location and Tracking Simulation in Industrial Indoor Environments. Electronics. 2019. Volume 8(10). P. 1152. https://doi.org/10.3390/electronics8101152.

6. Binyam Shiferaw Heyi, Implementation of Indoor Positioning using IEEE802.15.4a (UWB). A Thesis submitted for partial fulfillment of the Masters of Science in Electrical Engineering Major in Network Services And Systems (Stockholm, Sweden January, 2013).

7. Si4432 - Silicon Labs // [Electronic resource] / - Access: https://www.silabs.com/documents/public/datasheets/Si4430-31-32.pdf (access date 12.09.2020) 
8. Si446x Data Sheet - Silicon Labs // [Electronic resource] // - Access: https://www.silabs.com/ documents/public/data-sheets/Si4464-63-61-60.pdf (access date 12.09.2020)

9. CC1101 data sheet, product information and support|TI.com // [Electronic resource] // - Access: https://www.ti.com/product/CC1101 (access date 12.09.2020)
10. hc-12 wireless rf uart communication module v2.4 user manual // [Electronic resource] // - Access: https://statics3.seeedstudio.com/assets/file/bazaar/prod uct/HC-12 english datasheets.pdf (access date 12.09.2020)

11. HC-11Wireless Serial Port Module Elecrow.com // [Electronic resource] // - Access: https://www.elecrow.com/download/HC-11.pdf (access date 12.09.2020)

\section{Мошенський А. О. ПРИВАТНИЙ РЯТУВАЛЬНИЙ ЕХО-МАЯК 3 РАДІОМОДУЛЕМ FSК}

Рятувальний персонал пращює в середовищі високого ризику. В результаті травм може виникнути проблема евакуації рятувальника з об'єкту. GPS-навігація недоступна в зонах обмеженого доступу, наприклад, у кімнатах, підвалах. Раціональне використання радіовідповідачів для наведення об'єкта в напрямку. Комплекс прямого пошуку радіостанцій не завжди зручний і його можна швидко розгорнути, наприклад, у підвалі на випадок пожежі. Зручніше використовувати метод сліпого пошуку з існуючими УКВ-радіостанціями. Професійні радіостаниії, як правило, не мають індикатора потужності сигналу і мають обмежені засоби управління, такі як гучність, вибір каналу та РТT.

Запропоновано використовувати відповідач несівної на заданій частоті на основі SI44XX із поетапно регульованою потужністю та синхронною зміною тону заповнення звуку в режимі FSK або GFSK.

Для изього можна використовувати трансивери SI4432, SI4463, CC1101. РЧ потужності 100-10 мBm иілком достатньо. Всі вони можуть працюювати в режимах FSK GFSK та ASK. Найширший діапазон частот має SI4463 і охоплює основні діапазони 136-174 МГи та 400-470 (512) МГи.

Управління радіомодулем здійснюється через шину SPI; для генераџії тону один з GPIO налаштований як двійковий вхід даних у режимі FSK. Для реагування відповіді модуль відстежує зміну RSSI $i$, якщо його перевищено, перемикається в режим передачі. Для управління радіомодулем достатньо простого 8-бітового контролера з 8 (6) висновками та підтримкою SPI.

Потужності в $100 \mathrm{mBm}$ більш ніж достатньо, навіть з дуже укороченою гвинтовою або іншою сурогатною антеною. Допускається діапазон пошуку в сотні метрів. Кількість РЧ рівнів потужності може бути 3-4. Це може бути до 7 із зовнішнім аттенюатором на клавішах SPDT. Крок зміни потужності становить 6-10 дБ. Тони зростають, чітко чутні в діапазоні 400-2000 Ги. Ця система після навчання персоналу може бути корисною при пошуку жертви в умовах нульової видимості з точністю менше від метра до декількох метрів у приміщенні.

Ключові слова: маяк; УКХ; ЧМ; МК; потужність; тон.

\section{Moshenskyi A. \\ PRIVATE RESCUE ECHO BEACON WITH FSK RADIOMODULE}

Rescue personnel work in high-risk environments. As a result of injuries, the problem of evacuating the lifeguard from the facility may arise. GPS navigation is not available in restricted areas, for example, in rooms, basements. Rational use of radio responders for direction finding of the object. A radio direct finding complex is not always convenient and can be quickly deployed, for example, in a basement in case of fire. It is more convenient to use the blind bearing method with existing VHF radio stations. Professional radio stations usually do not have an indicator of signal strength, and have limited controls such as volume, channel selection, and PTT. It is proposed to use a carrier transponder at a given frequency based on SI44XX with stepwise adjustable power and synchronously changing audio filling tone in FSK or GFSK mode.

Transceivers SI4432, SI4463, CC1101 can be used for this reason. RF power 100-10 $\mathrm{mW}$ is enough. All of them can work in FSK GFSK and ASK modes. Widest frequency range have SI4463 and it cover main bands $136-174 \mathrm{MHz}$ and 400-470(512) $\mathrm{MHz}$.

The radio module is controlled via the SPI bus; to generate a tone, one of the GPIOs is configured as a binary data input in FSK mode. To implement the response, the module monitors the change of the RSSI and, if it available, switches to the transmission mode. To control the radio module, a simple 8-bit controller with 8 (6) pins and SPI support is enough. A power of $100 \mathrm{~mW}$ is more than enough, even with a very shortened helical or other surrogate antenna. Search range of hundreds of metrs is allowed. The number of RF power levels can be 3-4. It can be incree to 7 with an external attenuator on SPDT keys. The power change step is 6-10 dB. The tones are rising, clearly audible in the range of 400-2000 Hz. This system, after the staff training can be useful in the search for the victim in conditions of zero visibility with an accuracy of less than a meter to a few meters in the premises.

Keywords: Beacon; VHF(UHF); FSK; MCU; power; tone. 


\section{Мошенский А. А. \\ ЧАСТНЫЙ СПАСАТЕЛЬНЫЙ ЭХО-МАЯК С РАДИОМОДУЛЕМ FАК}

Спасательный персонал работает в условиях повышенного риска. В результате травм может возникнуть проблема эвакуации спасателя с объекта. GPS-навигация недоступна в зонах ограниченного доступа, например, в комнатах, подвалах. Рациональное использование радиопеленгаторов для пеленгации объекта. Комплекс радиопеленгации не всегда удобен и может быть быстро развернут, например, в подвале при пожаре.

Метод слепого пеленга удобнее использовать с существующими УКВ радиостанииями. Профессиональные радиостанции обычно не имеют индикатора мощности сигнала и имеют ограниченные элементы управления, такие как громкость, выбор канала и РТT.

Предлагается использовать транспондер несущей на заданной частоте на базе SI44XX с ступенчатой регулировкой мошности и синхронно изменяюшимся тоном заполнения звука в режиме FSK или GFSK.

По этой причине можно использовать трансиверы SI4432, SI4463, CC1101. ВЧ мощности 100-10 мBm вполне достаточно. Все они могут работать в режимах FSK GFSK и ASK. Самый широкий частотный диапазон у SI4463, он покрывает основные диапазоны 136-174 МГци и 400-470 (512) МГи.

Управление радиомодулем осуществляется по шине SPI; для генерации тона один из GPIO настраивается как ввод двоичных данных в режиме FSK. Для реализации ответа модуль отслеживает изменение RSSI и, если он более предела, переключается в режим передачи. Для управления радиомодулем достаточно простого 8-битного контроллера с 8 (6) контактами и поддержкой SPI.

Мощности 100 мВт более чем достаточно, даже с очень укороченной спиральной или другой суррогатной антенной. Допускается диапазон поиска в сотни метров. Количество уровней мошности ВЧ может составлять 3-4. Может быть до 7 с внешним аттенюатором на ключах SPDT. Шаг изменения мощчности 6-10 дБ. Тона нарастают, отчетливо сльшны в диапазоне 400-2000 Ги.

Эта система после обучения персонала может быть полезна при поиске пострадавщего в условиях нулевой видимости с точностью от метра до нескольких метров в помещении.

Ключевые слова: маяк; УКВ; ЧТ; МК; мощность; тон.

Стаття надійшла до редакції 16.11 .2020 p. Прийнято до друку 10.12 .2020 p. 